\title{
GAMBARAN PENGETAHUAN SISWA KELAS XII SMA NEGERI 7 MANADO TENTANG KATARAK
}

\author{
${ }^{1}$ Valeria Legoh \\ ${ }^{2}$ J.S.M Saerang \\ ${ }^{2}$ Laya Rares \\ ${ }^{1}$ Kandidat Skripsi Kedokteran Universitas Sam Ratulangi Manado \\ ${ }^{2}$ Bagian Ilmu Kesehatan Mata Fakultas Kedokteran Universitas Sam Ratulangi Manado \\ Email : legohvaleria@yahoo.com
}

\begin{abstract}
Cataract is a conditin of the occurance of cloudiness in the lens of the eye. The incidence of cataracts are often found in the elderly people and usually occurs due to the aging process. Cataract is the highest causes of blindness in Indonesia. North sulawesi is a region with the highest incidence of cataract in Indonesia.

One of the reason why the incidence of cataract is still high today, it's because most of the patient didn't know if they are suffering from cataract so that refuse the surgery. There are still many people who don't know clearly about cataract. Knowledge is the important thing in the occurance of a disease. The purpose of this research is to determine the description of knowledge about cataract against the school students, especially the XII grade students of SMA Negeri 7 Manado. This research uses a descriptive research design, with amount sample 78 respondent and the data was taken by answering the questionnaire. The result of these study shows that the level of knowledge from grade XII student of SMA Negeri 7 Manado about cataract is classified in good category with percentage $73,2 \%$.
\end{abstract}

\section{Keywords : Knowledge, student, cataract}

\begin{abstract}
Abstrak : Katarak merupakan kondisi terjadinya kekeruhan pada lensa mata. Kejadian katarak sering ditemukan pada orang lanjut usia dan biasanya terjadi karena proses penuaan. Katarak merupakan penyebab kebutaan tertinggi di Indonesia. Provinsi Sulawesi Utara merupakan daerah dengan angka kejadian katarak tertinggi di Indonesia. Salah satu alasan mengapa tingginya kejadian katarak sampai saat ini, yaitu karena sebagian besar pasien banyak yang tidak tahu apabila mereka menderita katarak sehingga menolak melakukan operasi. Masih banyak orang yang belum mengetahui secara jelas tentang katarak. Pengetahuan memiliki peran yang penting dalam terjadinya suatu penyakit. Tujuan dari penelitian ini adalah untuk mengetahui gambaran pengetahuan tentang katarak pada siswa sekolah khususnya siswa kelas XII SMA Negeri 7 Manado. Pada penelitian ini, metode yang digunakan adalah deskriptif dengan sampel sebanyak 78 responde dan pengambilan data diperoleh dengan menjawab kuesioner. Dari penelitian yang telah dilakukan, diperoleh tingkat pengetahuan responden tergolong dalam kategori baik (73,2\%).
\end{abstract}

Kata kunci : pengetahuan, siswa, katarak 
Mata merupakan satu organ vital yang sangat penting nilainya bagi manusia.Dengan mata, manusia dapat memperoleh banyak informasi visual yang digunakan untuk melaksanakan berbagai kegiatan. Namun gangguan terhadap penglihatan banyak terjadi, mulai dari gangguan ringan hingga gangguan yang berat yang dapat mengakibatkan kebutaan. ${ }^{1}$ Kebutaan merupakan isu global, terutama bagi Negara- Negara dengan prevalensi kebutaan yang tinggi karena kebutaan tidak hanya berdampak terhadap kehidupan sosial penderita namun juga memberikan dampak bagi ekonomi negara karena produktifitas seseorang yang menjadi buta akan menurun dan hidupnya akan bergantung pada orang lain. ${ }^{2}$

World Health Organization (WHO) memperkirakan terdapat 45 juta penderita kebutaan di dunia, dimana sepertiganya berada di Asia Tenggara. Dibandingkan dengan negara-negara regional Asia Tenggara, presentase kebutaan yang tertinggi adalah Indonesia dengan presentase $(1,5 \%)$ kemudian diikuti oleh (Bangladesh (1\%), india (0,7\%), dan Thailand (0,3\%). Menurut survey ksehatan penglihatan dan pendengaran tahun 19931996, penyebab utama kebutaan di Indonesia adalah katarak (0,78 \%), glaukoma (0,20\%), kelainan refraksi $(0,14 \%)$ dan penyakit - penyakit lain yang berhubungan dengan usia lanjut $(0,38 \%))^{3}$

Tingkat kebutaan yang diakibatkan oleh katarak di Indonesia merupakan yang tertinggi di Asia Tenggara, sedangkan dalam catatan WHO tingkat kebutaan di Indonesia berada diurutan ketiga didunia. Tingginya katarak di Indonesia dipengaruhi letak geografis yang berada di daerah garis khatulistiwa sehingga berdasarkan penelitian menilai masyarakat Indonesia resiko 15 tahun lebih cepat terkena katarak dibanding penduduk di Eropa. ${ }^{3}$

Katarak merupakan kelainan pada mata yang berupa kekeruhan pada lensa. Sehingga mengakibatkan gangguan penglihatan karena obyek menjadi kabur, penglihatan sentral menghilang, bahkan bisa sampai menjadi buta. ${ }^{4}$ Katarak sangat umum terjadi pada manula karena proses penuaan.Namun dapat juga terjadi pada masa anak - anak akibat infeksi sejak masih dalam masa kandungan dan berkembang akibat cedera. ${ }^{5}$

Dari data RISKESDAS tahun 2013, Sulawesi Utara memiliki prevalensi kejadian katarak tertinggi di Indonesia. Menurut data yang ada alasan utama mengapa pasien tidak melakukan operasi katarak karena pasien tersebut tidak mengetahui kalau dia sedang menderita katarak. $^{6}$

\section{METODE PENELITIAN}

Jenis penelitian yang dilakukan bersifat deskriptif yang bertujuan untuk menggambarkan pengetahuan siswa SMA Negeri 7 Manado tentang katarak. Penelitian ini dilaksanakan pada bulan November 2015 dan tempat penelitian di SMA Negeri 7 Manado. Populasi pada penelitian ini adalah siswa kelas XII SMA Negeri 7 Manado. Sampel penelitian ini diambil dari sebagian populasi yang sesuai dengan kriteria inklusi, seperti siswa kelas XII SMA Negeri 7 Manado yang hadir dan bersedia dengan sukarela untuk menjadi subjek penelitian.

\section{HASIL PENELITIAN}

Kuesioner dibagikan pada sebagian populasi yang memenuhi kriteria inklusi dan diperoleh sebanyak 81 responden. Tiga responden termasuk kriteria ekslusi, sehingga subjek penelitian menjadi 78 responden. Berikut ini akan diuraikan hasil penelitian dalam bentuk tabulasi dan penjelasan. 


\section{Pengetahuan siswa berdasarkan jenis kelamin}

Tingkat pengetahuan responden berdasarkan jenis kelamin diketahui bahwa responden perempuan memiliki pengetahuan yang tergolong cukup dengan presentase $44,70 \%$ dan responden laki-laki yang tergolong kurang dengan presentase 28,40\% (Tabel 1).

Tabel 1. Distribusi tingkat pengetahuan responden berdasarkan jenis kelamin

\begin{tabular}{cllll}
\hline $\begin{array}{c}\text { Jenis } \\
\text { Kelamin }\end{array}$ & $\begin{array}{l}\text { Jumlah } \\
\text { Responden }\end{array}$ & $\begin{array}{l}\text { Hasil } \\
\text { skoring } \\
\text { responden } \\
\text { yang } \\
\text { menjawab } \\
\text { benar }\end{array}$ & $\%$ & Kategori \\
& & 222 & 28,4 & Kurang \\
\hline L & 32 & 349 & 44,7 & cukup \\
\hline
\end{tabular}

\section{Pengetahuan siswa berdasarkan umur}

Pengetahuan responden berdasarkan umur, diketahui umur 16 tahun berpengetahuan kurang dengan presentase 25,5\%, sedangkan umur 17 tahun tingkat pengetahuannya tergolong cukup dengan presentase 47,6\% (Tabel 2).

Tabel 2. Distribusi tingkat pengetahuan responden berdasarkan usia

\begin{tabular}{lllll}
\hline Usia & $\begin{array}{l}\text { Jumlah } \\
\text { Responden }\end{array}$ & $\begin{array}{l}\text { Hasil } \\
\text { skoring } \\
\text { responden } \\
\text { yang } \\
\text { menjawab } \\
\text { benar }\end{array}$ & $\%$ & kategori \\
\hline 16 & 28 & 199 & 25,5 & Kurang \\
17 & 50 & 372 & 47,6 & Cukup \\
\hline
\end{tabular}

\section{BAHASAN}

\section{Karakteristik Responden}

Responden pada penelitian ini berjumlah 78 responden, sebagian besar berjenis kelamin perempuan dengan jumlah 46 orang (59\%) dan responden berjenis kelamin laki-laki berjumlah 32 orang (41\%). Berdasarkan tingkat pengetahuan yang diteliti diketahui tingkat pengetahuan responden perempuan tergolong cukup dibandingkan laki-laki yang masih tergolong kurang.

Berdasarkan usia responden yang diteliti, sebagian besar responden berusia 17 tahun sebanyak 50 orang (64\%) dan responden yang berusia 16 tahun sebanyak 20 orang (36\%). Tingkat pengetahuan responden yang berusia 16 tahun tergolong kurang sedangkan tingkat pengetahuan responden yang berusia 17 tahun tergolong cukup. Pada hasil ini dapat dilihat bahwa bertambahnya usia seseorang berpengaruh pada pertambahan pengetahuan yang diperolehnya. ${ }^{7}$ Usia seseorang yang lebih dewasa atau lebih tua akan lebih mudah dalam memberikan tanggapan atau respon dalam hal apapun berdasarkan tingkat pendidikan dan berbagai macam pengalaman yang pernah dialami. Seseorang yang usianya lebih tua tentu telah memiliki pengalaman yang lebih dalam berbagai macam hal. Salah satunya dalam hal memperoleh informasi dan pengetahuan tentang sesuatu yang baru, hal ini dapat dilihat dalam hasil penelitian.

\section{Pengetahuan Siswa Kelas XII SMA Negeri 7 Manado Tentang Katarak}

Pengetahuan merupakan salah satu faktor yang sangat berperan penting dalam berbagai hal. Seperti contohnya dalam pengembagan kesehatan seseorang, semakin banyak pengetahuan seseorang tentang kesehatan maka akan semakin baik juga tingkat kesehatan seseorang. Rendahnya pengetahuan mengenai kesehatan merupakan faktor yang mengarah kepada timbulnya penyakit. Untuk itu sangat penting bagi kita untuk memberikan informasi dan pengetahuan yang lebih akan hal tersebut. Berdasarkan hasil penelitian secara keseluruhan, pengetahuan siswa kelas XII SMA Negeri 7 Manado tentang katarak tergolong dalam kategori baik dengan presentase (73,2\%).

Katarak merupakan penyakit yang sering terjadi saat ini, sehingga banyak sekali informasi tentang katarak yang dapat diperoleh baik dari media cetak maupun media elektronik. Banyaknya 
sumber informasi saat ini yang dapat mempermudah seseorang mendapatkan informasi yang baru. Dalam hasil ini informasi memberikan pengaruh yang sangat penting pada pengetahuan seseorang. Meskipun seseorang memiliki pendidikan yang rendah dalam hal ini siswa yang masih duduk di bangku SMA tetapi jika ia mendapatkan informasi yang baik dari berbagai media hal itu akan meningkatkan kemampuan seseorang. ${ }^{7}$

\section{SIMPULAN}

Berdasarkan hasil penelitian dan pembahasan maka dapat diambil kesimpulan bahwa, pengetahuan siswa kelas XII SMA Negeri 7 Manado tergolong baik $(73,2 \%)$

\section{DAFTAR PUSTAKA}

1. Infodatin. Situasi gangguan penglihatan dan kebutaan. Jakarta: 2014. h.2

2. Perdami. Diakses dari : Perdamisulsel.org/dokumen/glauco ma_handouts.pdf (26 september 2015 )

3. Departemen kesehatan R.I . rencana strategi nasional : penanggulangan gangguan penglihatan dan kebutaan (PGPK) untuk mencapai vision 2020. Jakarta; 2005. h. 4-5

4. Anonim. Gambaran pengetahuan kepala keluarga tentang katarak. Diakses dari http://www.scribd.com/doc/142013 696/Gambaran-PengetahuaanKepala-Keluarga-TentangKatarak\#scribd (2 oktober 2015)

5. Singapore national eye center. Katarak. Singapore; 2013. Diakses dari : http://www.snec.com.sg/about/inter national/menuutama/kondisimataan dperawatan/commonproblems/Pages/Cataract.aspx (26 september 2015)
6. Kementerian kesehatan R.I. Riset kesehatan dasar. Jakarta; 2013. h. 240-243

7. Anonim. Diakses dari : http://repository.usu.ac.id//bitstrea m/123456789/20219/4/chapter20II. pdf (12 oktober 2015) 
